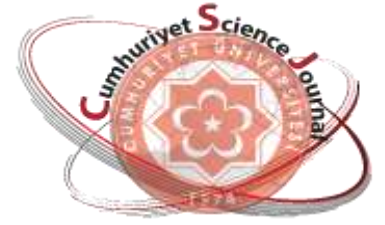

e-ISSN: 2587-246X

ISSN: $2587-2680$

\section{Cumburiys ot Seionee Journal}

esJ

Cumhuriyet Sci. J., Vol.39-1(2018) 258-273

\title{
The Trend Analysis of Lakes Region Precipitation Data in Turkey
}

\author{
Dilek TAYLAN*, Tuba AYDIN \\ Süleyman Demirel University, Engineering Faculty, Department of Civil Engineering, Isparta TURKEY
}

Received: 17.07.2017; Accepted: 13.03.2018

http://dx.doi.org/10.17776/csj.406271

\begin{abstract}
In recent years, population growth, urbanization, tainted water use policies, water pollution due to industrialization and climate change has led to the re-evaluation of water resources. Because the protection plans developed in the past have lost their validity, the new prevention plans made today have caused to the critical analysis. In this research, the monthly precipitation data was analyzed for Lakes Region located in the Middle Mediterranean Regionin Turkey. For this purpose, the data were subjected to homogeneity test, and the Mann Kendall test, the Sen's test and the lineer regression for trend analysis were applied to data. The analyses for historical monthly precipitation records were made to nine meteorological stations which identified in the study area:the Ağlasun, Barla, Aksu, Bucak, Yalvaç, Sütçüler, Kızılkaya, Kasımlar, and Gelendost stations. Also, 3, 6, 9, 12 monthly Standardized Precipitation Index (SPI) values of these stations were examined by using the Mann Kendall test, Sen's test and lineer regression to support historical trend analysis. According to the results of the tests, a decreasing trend has been observed in most of the nine stations.
\end{abstract}

Keywords: Lakes Region, precipitation, Mann Kendall test, Sen's test, linearregression

\section{Göller Bölgesi Yağış Verileri Trend Analizi}

Özet: Son yıllarda nüfus artışı, kentleşme, atık su kullanım politikaları, sanayileşme ve iklim değişikliği nedeniyle su kirliliği su kaynaklarının yeniden değerlendirilmesi konusunu gündeme getirmiştir. Geçmişte geliştirilen koruma planlarının geçerliliğini yitirmesi nedeniyle, bugün yapılan yeni önlem planları kritik analizler gerektirmektedir. Bu araştırmada, Türkiye'nin Orta Akdeniz Bölgesi'nde yeralan Göller Bölgesi aylık yağış verileri incelenmiştir. Bu amaçla verilere homojenlik testi uygulandıktan sonra, Mann Kendall testi, Sen testi ve lineer regresyon analizi uygulanmıştır. Tarihi aylık yağış kayıtlarınıntrendanalizi, çalışma alanında belirlenen Ağlasun, Barla, Aksu, Bucak, Yalvaç, Sütçüler, Kızılkaya, Kasımlar ve Gelendost meteoroloji istasyonları için yapılmıştır. Ayrıca, tarihi yağış kayıtlarının sonuçlarını desteklemek için bu istasyonların 3, 6, 9, 12 aylık Standart Yağış İndeksi (SYİ) metodu ile elde edilmiş kuraklık serilerinin trend analizleri de, Mann Kendall testi, Sen testi ve lineer regresyonu kullanılarak incelenmiştir. Uygulanantestlerin sonuçlarına göre, dokuz istasyonun çoğunda azalma eğilimi gözlenmiştir.

AnahtarKelimeler: Göller Bölgesi, yağış, Mann Kendall testi, Sen'in testi, lineer regresyon

\section{INTRODUCTION}

The climate could be defined as the average situation of the weather conditions during many years for anywhere in the world. At the same time, the climate conditions do not only include values close to the average values. They have extreme values and statistical variations. In a general approach, the climate change could be defined as the slow-growing and long-term

\footnotetext{
* Corresponding author. Email address: dilektaylan@sdu.edu.tr

http://dergipark.gov.tr/csj C2016 Faculty of Science, Cumhuriyet University
} 
changes[1]. Climate changes have emerged as major changes in the average temperature of the various regions of the world's glaciers during the Glacial timesAccording to our current information, there had been many changes in the Earth's climate system over a long geological history by natural ways. The sealevel changes and particularly glacial movements have created the lasting changes in the world ecological system at geological periods [2]. At the same time, the climate change has been identified by Ediger as the situation arising from the disruption of the natural greenhouse effect in the atmosphere by humans[3].

Both the effects of the climate changes on the hydrological cycle, water resources, and their local-regional global management and distribution have been growing day by day. These effects have occurred slowly during long period and the humanity feels these harmful signals nowadays. For this reason, the effects of climate changes should be necessarily examined at the development of the water supply studies. To observe the effects of the climate changes, the relationships between the climate changes and precipitation, evaporation, soil moisture, groundwater recharge, runoff, drought, and water quality should be examined in detail in the watershed. Also, the temporal changes of these hydrological parameters should be observed. For this purpose, the very different studies have been realized in hydrology and meteorology fields.

The hydrological variables such as temperature, rainfall, evaporation are parameters changing depending on time and place. The nonparametric methods are used to examine the variation of these parameters. The normality, linearity and independence are basic assumptions used in the classical parametric tests [4]. On the other hand, these basic assumptions are generally not suitable for some variables. For this reason, the non-parametric tests give better results than the parametric tests. The nonparametric tests are Sen's test,
Spearman's Rho test, Mann-Kendall test and seasonal Kendall test.

The rainfall is the major source of variability in water balance in space and time. The changes occurring in rainfall can have very important consequences for hydrology and water resources. Sen (2005) said that the hydrological changes may occur over time in a watershed [5]. These hydrological changes are affected by the changes occurring in precipitation at time periods of daily, seasonal, annual and tenyears.

The measured values may increase or decrease over time. Thesedecreases and increases are investigated with statistical tests in a meaningful way. The hydrological quantities (as like precipitation, flow and etc.) have randomly changing character over time. For this reason, the investigation of a continuous increase or decrease trend is possible with special methods [6].

Keskin et al (2015) observed montly and annual water level data for Eğirdir Lake. They used Run, Mann-Kendall and Sen'stestsfor monthly and annual water level data. As a result of this study, the annual water level decrease is approximately $0.026 \mathrm{~m}$. If all conditions exist as now, the June water level is expected to be $2.6 \mathrm{~m}$ for in a period of 100 years[7].

Serrano et al (1999) have applied the MannKendall test for monthly and annual precipitation data at 40 stations on the Iberian Peninsula between 1921-1995 years. As a result of the test, an increase was observed at one station in annual precipitation data, on the other hand a decrease was observed at fivestations. For monthly precipitation data, the decreases occurred in 21 of 40 stations in March. The significant decrease was observed fortwo stations in May. It was determined that the increase is only in two stations for July[8].

Türkeş (1996) applied Mann-Kendall test for annual and seasonal precipitation data at 91 stations between 1930 to 1993 years. The according to the test results, the decrease was 
observed in the Mediterranean and the Black Sea regions. In the annual series, it was seen a decreasefor precipitation in Turkey[9].

Gan (1998) applied Mann-Kendall test to the temperature and precipitation data from 1949 to 1989 for 37 stations in Canada. As a result of the test, the temperature increased and the drought process is taken for $40-50$ years. It was seen that the temperature was more effective than precipitation in begin of drought[10].

Topaloğlu et al. (1997) applied Mann-Kendall test for three stations founded in the closed basin of Lake Van for 25 years data. They determined that there was a statistically significant decrease in one of the stations and there was no significant decrease in the other two stations[11].

Yue and Wang (2002) have implemented the Regional Mann-Kendall test on the annual average, maximum and minimum flow datafor ten different geographical regions in Canada between the years 1967-1996. As a result of the tests, for the average flows, the decrease was occurred for two geographical regions and the increase was observed in one geographic region. Otherwise, there was no trend of increase or decrease in seven geographical regions. The test results of the maximum flows show that the decrease was observed in sixregions, on the other hand there were no significant trends in four regions. For minimum flows, the decrease occurred inthree geographic regions[12].

Yue and Hashino (2003) applied the MannKendall Rank Correlation test to the 22 stations for nearly 100 years of data in the three different geographical regions in Japan. As a result of studies, the increase occurred in May; the decreases were observed in December, April, September, and October forthe first region. In the second region, a reduction has been observed in annual and monthly rainfall. In the third region, the most reduction has occurred for annual rainfall in July[13].
Rahmat et al. (2012) formed the trend analysis by using nonparametric trend tests: Mann Kendall and Spearman's rho for five selected meteorological stations in Victoria. For the drought analysis, the Standardized Precipitation Index (SPI) was applied to 3 month and 12 month time scales using monthly mean precipitation data for the time series of over 60 years. They said that the computed SPI values for both time scales showed statistically significant downward trend for all stations[14].

Jha et al. (2011) carried out to compute spatiotemporal trends in Standardized Precipitation Index (SPI) for the 1951 - 2006 period for Indian landmass. They said that Regional Kendall test showed a significant positive trend in June SPI, while significant negative trends in SPI were observed for July and August in India[15].

Campra and Morales (2016) applied to piecewise regression to surface air temperature records in Southeastern Spain for the period of 1973-2014 by dividing the time series into linear segments with different slopes. They specified that piecewise regression model showed better fit than simple linear regression model and this model showed a better description of temperature variability[16].

Rehman (2013) formed Long-Term wind speed analysis and searched its trends using MannKendall Test and Linear Regression Method in Kingdom of Saudi Arabia. He used historical daily mean wind speed data measured at 8-12 $\mathrm{m}$ above ground level at national and international airports in the Kingdom over a period of 37 years to obtain long-term annual and monthly mean wind speeds, annual mean wind speed trends, and energy yield using an efficient modern wind turbine of $2.75 \mathrm{MW}$ rated power. Based on regression line analysis, the decreasing trends of annual mean wind speed were found at Al-Ahsa, AlBaha, Bisha, Dhahran, Gizan, Guriat, Hail, Khamis-Mushait, Madina, Makkah, Nejran, Qasumah, Riyadh, Sharourah, Tabouk, Taif, Wadi Al-Dawasser, 
and Yanbo, and the increasing trends at remaining locations, i.e. Abha, Al-Jouf, AlWejh, Gassim, Hafr Al-Batin, Jeddah, Rafha, Sulayel, Turaif, and WadiAlDawasser [17].

Bacanl1 (2017), investigated the variability in the 1, 3, 6, 9, 12 and 24 monthly SPI in the Aegean Region of Turkey and formed trend analysis with Mann-Kendall and Spearman's rho methods in the1, 3, 6, 9, 12 and 24 monthly SPI. She said that the trend analyses of precipitation are in parallel with the results of drought analyses and a decrease of the monthly SPI series refered to an increase in drought[18].

In the study, the monthly precipitation data obtained from Turkish State Meteorological Service for Ağlasun, Barla, Aksu, Burdur, Yalvaç, Sütçüler, Kızılkaya, Kasımlar, and Figure 1. Study Area.
Gelendost stations in Lakes Region is used. The precipitation values and the SPI values for 3,6 , 9, 12 months of these stations were examined by Mann Kendall test, Sen's test and Linear regression to investigate the trends over the course of different years period.

\section{MATERIALS and METHODS 2.1 Materials}

The Lakes Region lies the south of the Mediterranean in Turkey. Its surface area is $8933 \mathrm{~km}^{2}$ and it is located between $30^{\circ} 20^{\prime}-$ $31^{\circ} 33^{\prime} \mathrm{E}$ and $37^{\circ} 18^{\prime}-3830^{\prime} \mathrm{N}$. The mean altitude of the Lakes Region is $1050 \mathrm{~m}$ (Figure 1).

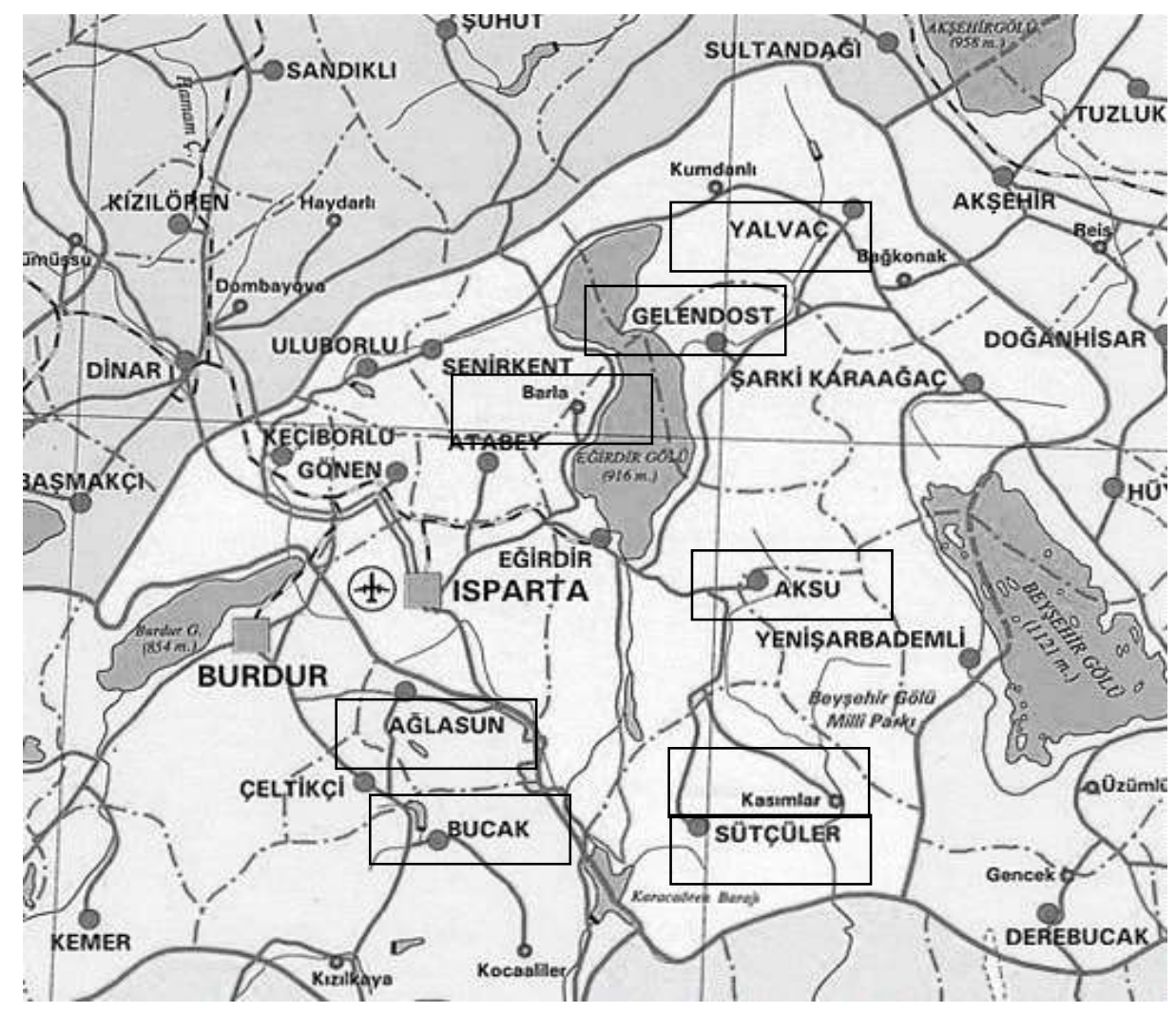

From climatologic analysis of long periods of observations, both Mediterranean and continental climate types are seen; while Mediterranean climate is observed in the south region and continental climate occurs in the north of this region. The mean annual precipitation is $551.8 \mathrm{~mm}$. The most $(72.69 \%)$ of the precipitation occurs in the winter and spring months, while the summer and autumn 
months are rather dry months of this region (29.31\% of total precipitation)[19].

In this study, rainfall data were examined for nine stations which located Lakes Region. These are Ağlasun, Aksu, Barla, Burdur, Gelendost, Kasımlar, Kızılkaya, Sütçüler and
Yalvaç stations. The precipitation data represents different years periodfor ninestations and these data have been taken from Turkish State Meteorological Service. It was given some statistics of nine stations in Table 1.

Table 1. The precipitation statistics of Lakes Region stations.

\begin{tabular}{|l|c|c|c|c|c|}
\hline Stations & Time interval & Maximum $(\mathbf{m m})$ & $\begin{array}{c}\text { Minumum } \\
(\mathbf{m m})\end{array}$ & $\begin{array}{c}\text { Avarage } \\
(\mathbf{m m})\end{array}$ & $\begin{array}{c}\text { Standard Deviation } \\
(\mathbf{m m})\end{array}$ \\
\hline Ağlasun & $1975-1992$ & 265.2 & 2.9 & 58.05 & 57.14 \\
\hline Barla & $1987-1992$ & 193.3 & 1.1 & 41.94 & 43.70 \\
\hline Aksu & $1993-2003$ & 349.4 & 1.2 & 69.49 & 70.96 \\
\hline Burdur & $1975-1999$ & 283.6 & 0.6 & 55.15 & 56.50 \\
\hline Yalvaç & $1964-2004$ & 2067 & 2 & 413.55 & 353.51 \\
\hline Sütçüler & $1975-1992$ & 345.8 & 0.5 & 79.16 & 78.21 \\
\hline Kuzılkaya & $1987-1990$ & 131.1 & 0.4 & 29.53 & 26.96 \\
\hline Kasımlar & $1987-1993$ & 580.5 & 1.2 & 76.40 & 90.63 \\
\hline Gelendost & $1983-1988$ & 145.6 & 1.5 & 41.25 & 37.23 \\
\hline
\end{tabular}

\subsection{Methods}

\subsubsection{Mann-Kendall Test}

The Mann- Kendall test is nonparametric and independent from the data distribution. The Mann-Kendall statistic S is given;

$\mathrm{S}=\sum_{\mathrm{i}=1}^{\mathrm{n}-1} \sum_{\mathrm{j}=\mathrm{i}+1}^{\mathrm{n}} \operatorname{sgn}\left(\mathrm{x}_{\mathrm{j}}-\mathrm{x}_{\mathrm{i}}\right)(1)$

The trend presence in a time series is investigated by the null hypothesis. The application of the trend test is done to a time series $x_{i}$ that is ranked from $i=1,2, \ldots \ldots \ldots, n-$ 1and $x_{j}$, which is ranked from $\mathrm{j}=$ $i+1,2, \ldots \ldots \ldots . . . n$. Each one of the data points $x_{i}$ is taken as a sample point which is compared with the rest of the data points $\mathrm{x}_{\mathrm{j}}$, so that follows

$$
\begin{aligned}
& +1,>\left(x_{j}-x_{i}\right)
\end{aligned}
$$

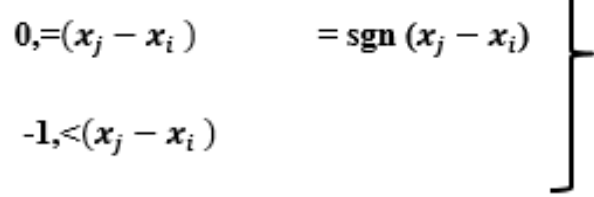

The variance of the $\mathrm{S}$ - statistic is calculated as;

$$
\operatorname{Var}(S)=\frac{n(n-1)(2 n+5)-\sum_{l=1}^{m} t_{i}(i)(i-1)(2 i+5)}{18}
$$

Where, $t_{i}$ is considered as the number of ties up to sample $\mathrm{i}$. The test statistics $\mathrm{Z}$ is calculated as follows [20]

$$
\begin{aligned}
& \frac{s^{\prime}-1}{\left[\operatorname{Var}\left(S^{\prime}\right)\right]} \text { if } \quad S^{\prime}>0 \\
& \frac{s^{\prime}+1}{\left[\operatorname{Var}\left(S^{\prime}\right)\right]} \text { if } \quad S^{\prime}<0 \\
& 0 \quad \text { if } \quad S^{\prime}=0
\end{aligned}
$$

\subsubsection{Sen's Test}

The linear slopes of trends are calculated using a nonparametric method which developed by 'Sen'[5]. Sen's test was performed in order to determine the change of slope in the monthly precipitation data of the Lakes Region. The slope estimates of $\mathrm{N}$ pairs of data are first computed by

$$
\mathrm{Q}_{i}=\frac{\left(x_{j}-x_{k}\right)}{j-k} \text { for } \mathrm{i}=1, \ldots, \mathrm{N}
$$


Where $x_{j}$ and $x_{k}$ are data values at times $\mathrm{j}$ and $\mathrm{k}$ $(\mathrm{j}>\mathrm{k})$ respectively. The median of these $\mathrm{N}$ values of $Q_{i}$ is Sen's estimator of slope. If $\mathrm{N}$ is odd, then Sen's estimator is computed by Qmed $\mathrm{D} \mathrm{QNC} 1 / 2$ and if $\mathrm{N}$ is even, then Sen's estimator is computed by $Q_{m e d}=\left[Q_{N / 2}+\right.$ $\left.Q_{(N+2) / 2}\right] / 2$. Finally, $Q_{m e d}$ is tested by a twosided test at the $100(1-\alpha) \%$ confidence interval and the true slope may be obtained by the nonparametric test [20].

\subsubsection{Linear Regression Analysis}

The regression analysis is an important general method in itself and a foundation of more sophisticated forecasting methods. It is a general approach to modeling the relationships between one variable, such as runoff, and one or more other variables, such as precipitation, slope, and infiltration rate. In linear regression methods, it was predicted the future by modeling the past relationships between the dependent variable and one or more other variables called independent. The dependent variable is commonly denoted by $\mathrm{Y}$ and the independent variables by $\mathrm{X}$ [21].

As shown in Figure 2, there are a variety of relationships existing between two variables in linear regression.

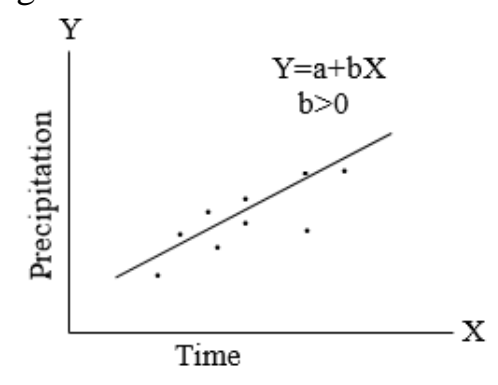

(a) Positive Linear

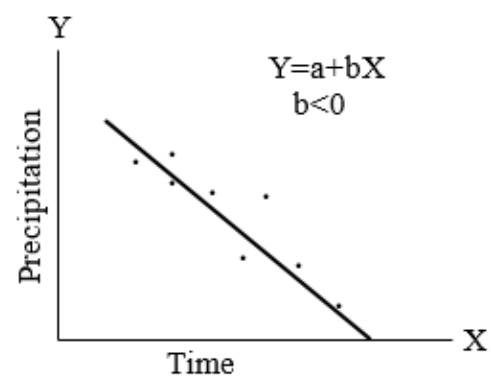

(b) Negative Linear

Figure 2. The relationships between dependent and independent variables [21].
The Figure 2a illustrates a positive linear relationship. The positive linear relationship refers to the direction of line as being up or positive to the right. However, Figure $2 b$ shows a negative linear relationship, so the direction of line is being down. Thus, it could be said that $\mathrm{b}$, slope of the line is bigger than zero and this line shows increasing trend in Figure $2 \mathrm{a}$ while $\mathrm{b}$ is smaller than zero and this line shows decreasing trend in Figure $2 b$.

\subsubsection{Standardized Precipitation Index (SPI)}

The standardized precipitation is simply the difference of precipitation from the mean divided by the standard deviation for a specified time period. Here, the mean and the standard deviation are determined from past records [22]:

$$
S P I=\frac{x-\bar{x}}{\sigma}
$$

Where $\mathrm{X}$ is monthly precipitation value, $\bar{X}$ is mean precipitation value and $\sigma$ is standart deviation of monthly precipitation.

The standardized precipitation is linearly proportional to precipitation deficit and allows specification of probability, percent of average and accumulated precipitation deficit. This method is used in different water resources applications.

Standardized Precipitation Index (SPI) is calculated from monthly precipitation data. The data set should have a period at least 30 years. The all data set is divided for a period of $\mathrm{m}$ months. The period of $m$ months is definedas a time scales of period i months. Here i could be selected 3,6,9,12,24 or 48 months. The data set is moving in the sense that each month a new value is determined from the previous i months [22]. 


\section{APPLICATION AND RESULTS}

\subsection{The Trend Analysis for theHistorical Precipitation Data}

The monthly precipitation data were analyzed in different periodsfor Ağlasun, Barla, Aksu,
Burdur, Yalvaç, Sütçüler, Kızılkaya, Kasımlar, and Gelendost stations. The trend analysis were realized for the monthly precipitation by using Mann Kendal test, Sen's test and Linear Regression slopes (Table 2).

Table 2. The results of trend analysis tests for the monthly historical precipitation data.

\begin{tabular}{|c|c|c|c|c|c|c|c|c|c|c|c|c|c|}
\hline 总 & $\begin{array}{l}\frac{n}{0} \\
\frac{1}{2} \\
\sum_{2}^{2}\end{array}$ & 怘 & 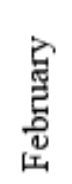 & 总 & 寻 & 忍 & $\stackrel{\Xi}{\Xi}$ & 当 & 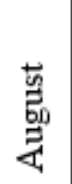 & 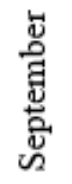 & 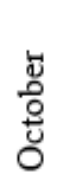 & 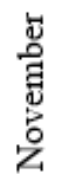 & 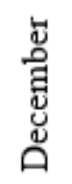 \\
\hline \multirow{3}{*}{ 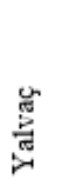 } & Mann Kendall & 0.34 & 0.26 & -0.29 & 0.70 & -0.25 & -1.38 & 0.19 & -0.35 & 0.38 & 0.47 & 0.69 & -0.43 \\
\hline & Şen's Method & 1.35 & 1.48 & -1.02 & 3.16 & -0.41 & -3.76 & 0.04 & -0.05 & 0.40 & 1.95 & 3.00 & -2.82 \\
\hline & Linear Reg. & 10.6 & 3.40 & 3.78 & 16.3 & 4.79 & -7.05 & -0.70 & -0.98 & -4.12 & -1.26 & -21.4 & 4.74 \\
\hline \multirow{3}{*}{ 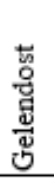 } & Mann Kendall & & & & & & & & & & & & \\
\hline & Şen's Method & -16.9 & 5.70 & 7.70 & -7.38 & 0.30 & -0.80 & 0.00 & 0.24 & -1.17 & -1.85 & -15.1 & -4.23 \\
\hline & Linear Reg. & -0.08 & -1.32 & -2.92 & -15.9 & -2.72 & 6.98 & -0.33 & -2.93 & -0.95 & 4.71 & -8.35 & 6.68 \\
\hline \multirow{3}{*}{$\begin{array}{l}\text { 苞 } \\
\text { صू }\end{array}$} & Mann Kendall & & & & & & & & & & & & \\
\hline & Şen's Method & -6.80 & -8.42 & -13.7 & -0.68 & 4.15 & 4.10 & 4.75 & -1.94 & -0.34 & 0.00 & -17.2 & 27.0 \\
\hline & Linear Reg. & -24.7 & -8.60 & -20.8 & 10.4 & 14.2 & -9.53 & -5.25 & -3.65 & 7.62 & 13.3 & -27.5 & 37.6 \\
\hline \multirow{3}{*}{ 苞 } & Mann Kendall & 0.21 & -0.15 & 1.12 & 0.73 & 2.24 & 0.30 & 0.86 & 0.58 & 1.00 & 0.03 & -0.79 & 0.73 \\
\hline & Şen's Method & 0.27 & -0.72 & 2.23 & 1.72 & 2.57 & 0.32 & 0.75 & 0.22 & 0.62 & 0.00 & -2.45 & 2.38 \\
\hline & Linear Reg. & -1.48 & -1.52 & 3.22 & -0.22 & 2.98 & -0.11 & -1.24 & 1.35 & 2.13 & 0.14 & -3.24 & 5.11 \\
\hline \multirow{3}{*}{ 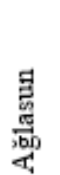 } & Mamn Kendall & -2.99 & -0.61 & 0.91 & 0.30 & -0.91 & -0.23 & 1.25 & -0.35 & -2.10 & -2.21 & -1.75 & -2.62 \\
\hline & Şen's Method & -10.3 & -1.86 & 2.43 & 0.80 & -2.13 & -0.15 & 0.98 & 0.00 & -1.17 & -3.56 & -3.59 & -7.17 \\
\hline & Linear Reg. & -8.90 & -0.20 & 1.32 & 2.23 & -3.35 & 0.13 & 1.26 & 1.25 & -1.13 & -4.43 & -1.64 & -1.25 \\
\hline \multirow{3}{*}{$\begin{array}{l}\text { 岕 } \\
\text { 志 } \\
\text { 总 }\end{array}$} & Mann Kendall & -3.26 & -0.30 & -0.19 & -1.97 & 0.30 & -0.30 & 1.92 & 0.88 & 0.00 & -0.76 & 0.08 & 0.38 \\
\hline & Şen's Method & -11.3 & -0.51 & -0.61 & -4.61 & 0.78 & -0.23 & 0.71 & 0.15 & 0.00 & -2.00 & 0.60 & 2.53 \\
\hline & Linear Reg. & -13.2 & -0.52 & -0.33 & -4.87 & -0.10 & -0.75 & 0.92 & 0.18 & 0.98 & -1.69 & 2.47 & 1.19 \\
\hline \multirow{3}{*}{ 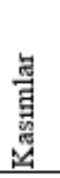 } & Mann Kendall & & & & & & & & & & & & \\
\hline & Şen's Method & -9.93 & -26.6 & -32.8 & -14.6 & -23.1 & -5.30 & -3.00 & -0.13 & 0.40 & -11.6 & -27.3 & -17.4 \\
\hline & Linear Reg. & -15.4 & -14.7 & -15.5 & -4.59 & -14.3 & -6.91 & 1.05 & 5.16 & 3.56 & 0.53 & -17.9 & 34.2 \\
\hline \multirow{3}{*}{ 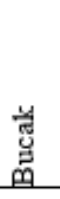 } & Mann Kendall & -0.51 & -0.35 & 1.87 & -0.68 & 0.91 & -0.23 & -0.47 & 0.28 & -1.22 & 0.19 & -0.05 & 0.75 \\
\hline & Şen's Method & -1.24 & -0.24 & 3.26 & -0.98 & 0.67 & -0.19 & -0.08 & 0.05 & -0.30 & 0.21 & -0.06 & 1.79 \\
\hline & Linear Reg. & -1.85 & -1.63 & 3.83 & -0.24 & 1.29 & 0.90 & 0.32 & 0.60 & -0.95 & 0.30 & -0.34 & 3.75 \\
\hline \multirow{3}{*}{ 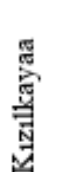 } & Mamn Kendall & & & & & & & & & & & & \\
\hline & Şen's Method & -6.35 & -8.12 & -15.9 & -26.5 & -8.99 & -9.20 & -4.45 & 1.22 & -0.38 & -13.0 & -14.8 & -23.1 \\
\hline & Linear Reg. & -1.65 & -13.4 & 2.05 & -36 & -14.3 & -26.7 & -7.75 & -4.15 & -0.45 & 14.3 & -1.90 & -12.9 \\
\hline
\end{tabular}


According to Table 2, the negative trends were especially seen for the monthly precipitations in Lakes Region. For some stations (Gelendost, Barla, Kasımlar, Kız1kaya), the Mann Kendall values were not given. It was not observed any meaningfull value for these stations because of the fact that the historical precipitation records were too short to apply this method. Only the Mann Kendall values of Yalvaç station for January, February, April, July, September, October, November gave positive values. Hence, for only Yalvaç station, there was the increasing trend. The Mann Kendall test results of 2 stations (Sütçüler

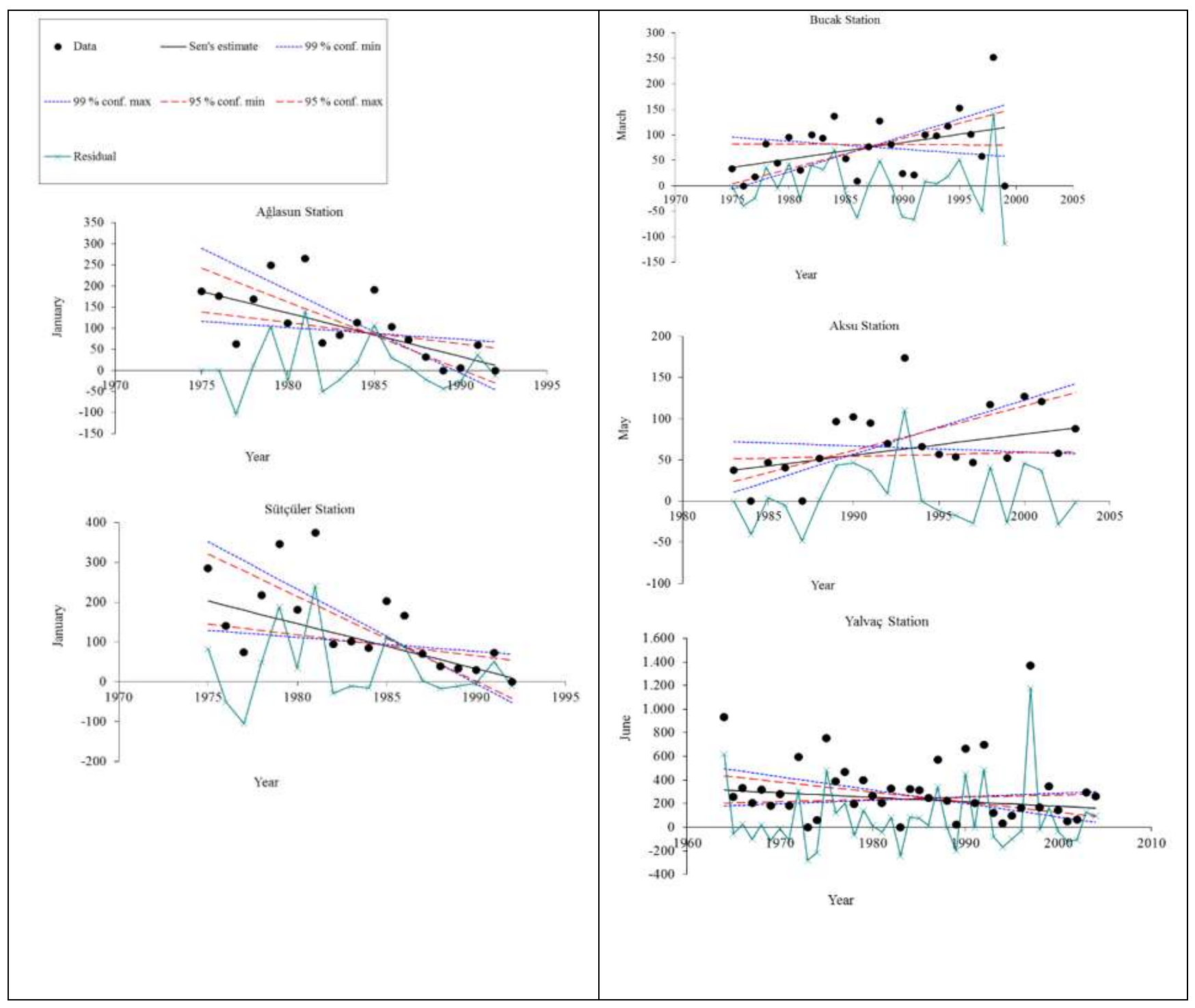

and Ağlasun) were given in Table 3 at common time interval. As seen from the Table 3, the decreasing trend was observed in Sütçüler and Ağlasun Stationsfor the years 1975-1992.

The Mann Kendall test graphics for precipitation data obtained from five stations were given in

Figure 3. The Mann Kendall test graphics shows that monthly precipitation data exhibit a significant decreasing trend for Ağlasun and Sütçüler stations on January. 
Sütçüler Station. It was not observed any meaningfull value for the other stations. Hence, it was not given values of other stations on Table 3 .

Table 3.The Mann-Kendall test of ' $z$ ' values for the years 1975-1992 for monthly precipitation data in Ağlasun and Sütçüler Stations.

SÜTÇÜLER STATION

\begin{tabular}{|l|l|l|r|r|l|r|r|r|r|}
\hline Months & First year & Last Year & $\mathbf{n}$ & Test S & Test Z & Signific. & Test S & Test Z & Signific. \\
\hline January & 1975 & 1992 & 18 & & -3.26 & $* *$ & & -2.99 & $* *$ \\
\hline February & 1975 & 1992 & 18 & & -0.30 & & & -0.61 & \\
\hline March & 1975 & 1992 & 18 & & -0.19 & & & 0.91 & \\
\hline April & 1975 & 1992 & 18 & & -1.97 & $*$ & & 0.30 & \\
\hline May & 1975 & 1992 & 18 & & 0.30 & & & -0.91 & \\
\hline June & 1975 & 1992 & 18 & & -0.30 & & & -0.23 & \\
\hline July & 1975 & 1992 & 18 & & 1.92 & + & & 1.25 & \\
\hline August & 1975 & 1992 & 18 & & 0.88 & & & -0.35 & \\
\hline September & 1975 & 1992 & 18 & & 0.00 & & & -2.10 & $*$ \\
\hline October & 1975 & 1992 & 18 & & -0.76 & & & -2.21 & $*$ \\
\hline November & 1975 & 1992 & 18 & & 0.08 & & & -1.75 & + \\
\hline December & 1975 & 1992 & 18 & & 0.38 & & & -2.62 & $* *$ \\
\hline
\end{tabular}

There is only meaningful value in Aksu station for This value $(2,24)$ shows the increasing trend for $\alpha=0,05$ confidence interval in May in Table 4. Aksu Station.

Table 4. Mann-Kendall test of ' $z$ ' values for the years 1983-2003 for monthly precipitation data in Aksu Station.

\begin{tabular}{|c|c|c|c|c|c|c|}
\hline Months & First year & Last Year & $\bar{n}$ & Test $\mathrm{S}$ & Test $\mathrm{Z}$ & Signific. \\
\hline January & 1983 & 2003 & 21 & & 0.21 & \\
\hline February & 1983 & 2003 & 21 & & -0.15 & \\
\hline March & 1983 & 2003 & 21 & & 1.12 & \\
\hline April & 1983 & 2003 & 21 & & 0.73 & \\
\hline May & 1983 & 2003 & 21 & & 2.24 & $*$ \\
\hline June & 1983 & 2003 & 21 & & 0.30 & \\
\hline July & 1983 & 2003 & 21 & & 0.86 & \\
\hline August & 1983 & 2003 & 21 & & 0.58 & \\
\hline September & 1983 & 2003 & 21 & & 1.00 & \\
\hline October & 1983 & 2003 & 21 & & 0.03 & \\
\hline November & 1983 & 2003 & 21 & & -0.79 & \\
\hline December & 1983 & 2003 & 21 & & 0.73 & \\
\hline
\end{tabular}

The Sen's slopes were given in Table 5 as an example for Bucak station. According to data in Table 5,the precipitation values of January, February, April, June, July, September and November months exhibit a statistical decreasing trend while this station exhibit increasing trend in March, May, August, October and December months. The slope values of other stationsare given in Table 6. According to Sen's test (Table 5 ), the decreasing trends were observed on January for Ağlasun, Sütçüler and Bucak stations as like Mann-Kendall test. For instance, there was the decreasing precipitation slope on January for Bucak station approximately. 
Table 5. The Sen's test values of Bucak Station for upper and lower limit values for $\% 95$ and $\% 99$ confidence interval.

\begin{tabular}{|c|l|l|l|l|l|l|l|l|}
\hline Months & First year & Last Year & $\mathbf{n}$ & $\mathbf{Q}$ & $\mathbf{Q}_{\min 99}$ & $\mathbf{Q}_{\max 99}$ & $\mathbf{Q}_{\min 95}$ & $\mathbf{Q}_{\max 95}$ \\
\hline January & 1975 & 1999 & 25 & -1.240 & -7.350 & 5.023 & -5.948 & 3.564 \\
\hline February & 1975 & 1999 & 25 & -0.242 & -4.869 & 2.954 & -3.821 & 1.814 \\
\hline March & 1975 & 1999 & 25 & 3.257 & -1.563 & 6.909 & -0.087 & 5.954 \\
\hline April & 1975 & 1999 & 25 & -0.976 & -3.743 & 2.658 & -3.050 & 1.888 \\
\hline May & 1975 & 1999 & 25 & 0.672 & -2.494 & 2.937 & -1.609 & 2.329 \\
\hline June & 1975 & 1999 & 25 & -0.188 & -1.995 & 3.126 & -1.546 & 2.154 \\
\hline July & 1975 & 1999 & 25 & -0.076 & -1.284 & 1.491 & -0.855 & 0.935 \\
\hline August & 1975 & 1999 & 25 & 0.049 & -0.504 & 0.948 & -0.308 & 0.562 \\
\hline September & 1975 & 1999 & 25 & -0.303 & -1.513 & 0.660 & -1.121 & 0.300 \\
\hline October & 1975 & 1999 & 25 & 0.206 & -2.676 & 3.467 & -2.123 & 2.580 \\
\hline November & 1975 & 1999 & 25 & -0.062 & -4.228 & 3.976 & -3.049 & 3.113 \\
\hline December & 1975 & 1999 & 25 & 1.791 & -4.221 & 7.858 & -3.117 & 6.249 \\
\hline
\end{tabular}

In Table 6, the meaningful value is $-1.24 \mathrm{~mm}$ and the expected minimum is $-5.948 \mathrm{~mm}$ and the expected maximum is $-3.564 \mathrm{~mm}$ for $\alpha=0.05$ confidence interval. If all conditions exist as now, then in 100 year period the decreasing of January precipitation value can be $-1.24 \mathrm{~mm}$.

Table 6. The slope values of Sen's test.

\begin{tabular}{|c|c|c|c|c|c|c|c|c|c|}
\hline & 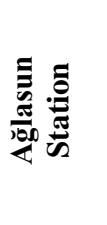 & 竝 & 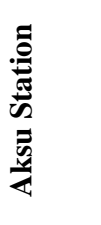 & 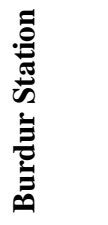 & 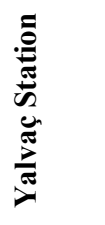 & 离 & 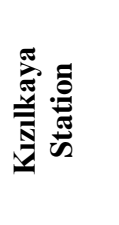 & 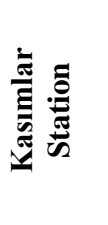 & 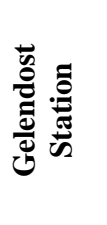 \\
\hline Months & $\mathrm{Q}$ & $\mathrm{Q}$ & $\mathrm{Q}$ & $Q$ & $\mathrm{Q}$ & $\mathrm{Q}$ & $\mathrm{Q}$ & $\mathrm{Q}$ & $\mathrm{Q}$ \\
\hline January & -10.28 & -6.80 & 0.27 & -1.24 & 1.34 & -11.31 & -6.35 & -9.92 & -16.90 \\
\hline February & -1.86 & -8.42 & -0.71 & -0.24 & 1.47 & -0.51 & -8.11 & -26.62 & 5.70 \\
\hline March & 2.42 & -13.75 & 2.22 & 3.25 & -1.01 & -0.61 & -15.86 & -32.80 & 7.70 \\
\hline April & 0.80 & -0.67 & 1.71 & -0.97 & 3.16 & -4.61 & -26.45 & -14.58 & -7.37 \\
\hline May & -2.12 & 4.15 & 2.57 & 0.67 & -0.40 & 0.78 & -8.99 & -23.10 & 0.30 \\
\hline June & -0.15 & 4.10 & 0.32 & -0.18 & -3.76 & -0.23 & -9.20 & -5.30 & -0.80 \\
\hline July & 0.98 & 4.75 & 0.74 & -0.07 & 0.03 & 0.70 & -4.45 & -3.00 & 0.00 \\
\hline August & 0.00 & -1.94 & 0.21 & 0.04 & -0.05 & 0.15 & 1.21 & -0.13 & 0.24 \\
\hline September & -1.17 & -0.34 & 0.62 & -0.30 & 0.40 & 0.00 & -0.37 & 0.40 & -1.16 \\
\hline October & -3.56 & 0.00 & 0.00 & 0.20 & 1.95 & -2.00 & -13.00 & -11.56 & -1.85 \\
\hline November & -3.59 & -17.25 & -2.44 & -0.06 & 3.00 & 0.60 & -14.83 & -27.30 & -15.15 \\
\hline December & -7.16 & 27.00 & 2.37 & 1.79 & -2.82 & 2.53 & -23.13 & -17.35 & -4.22 \\
\hline
\end{tabular}

\subsection{The Trend Analysis for SPI values of Historical Precipitation Data}

Keskin et al. (2009) formed meteorological drought analysis for the nine stations: Ağlasun, Barla, Aksu, Burdur, Yalvaç, Sütçüler, Kızılkaya, Kasımlar, and Gelendost in the Lakes Region, Turkey [23]. They determined that precipitation values fitted a gamma distribution. In this study, 3,6,9 and 12 monthly Standardized Precipitation Index (SPI) values of nine stations were examined with Mann Kendall test, Sen's test and Linear
Regression to support the trend analysis of historical precipitation data of Lakes Region. The SPI values of the stations were computed for 3, 6, 9 and 12 monthly periods. Then, the trend analysis methods were performed on the obtained standardized series for 3, 6, 9 and 12monthly periods of stations. The results of the trend analysis tests were given in Table 7, 8, 9, 10 for $3,6,9$ and 12 monthly standardized precipitation 
values of nine stations by using Mann Kendal test,

Sen's test and Linear Regression slopes.

Table 7. The results of trend analysis tests for the 3 monthly standardized precipitation values.

\begin{tabular}{|c|c|c|c|c|c|c|c|c|c|c|c|c|c|}
\hline 总 & 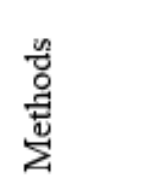 & 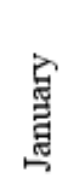 & 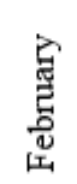 & 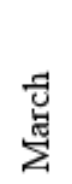 & 㝵 & 荥 & 㕦 & 츨 & 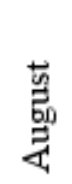 & 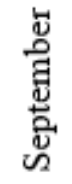 & 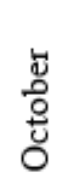 & $\begin{array}{l}\text { 岁 } \\
\text { 葛 } \\
\text { 号 } \\
\text { 艺 }\end{array}$ & 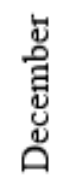 \\
\hline \multirow{3}{*}{ 荡 } & Mann Kendall & -0.06 & 0.17 & 0.43 & 1.01 & -1.04 & -0.73 & -0.06 & -1.32 & 0.41 & -0.10 & 0.36 & -0.43 \\
\hline & Şen's Method & 0.00 & 0.00 & 0.00 & 0.00 & -0.01 & 0.00 & 0.00 & -0.01 & 0.00 & 0.00 & 0.00 & 0.00 \\
\hline & Linear Reg. & 0.00 & 0.00 & 0.01 & 0.01 & -0.01 & 0.00 & -0.03 & -0.10 & -0.05 & 0.00 & 0.01 & 0.00 \\
\hline \multirow{3}{*}{ 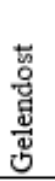 } & Mann Kendall & & & & & & & & & & & & \\
\hline & Şen's Method & 0.29 & -0.05 & -0.12 & -0.25 & -0.16 & 0.28 & -0.19 & 0.05 & 0.06 & 0.06 & -0.10 & -0.05 \\
\hline & Linear Reg. & 1.16 & 0.44 & -1.60 & -0.26 & -0.03 & 0.29 & 0.02 & -0.02 & 0.00 & 0.06 & -0.14 & 0.08 \\
\hline \multirow{3}{*}{$\begin{array}{l}\text { 莺 } \\
\text { ต }\end{array}$} & Mann Kendall & & & & & & & & & & & & \\
\hline & Şen's Method & -0.07 & 0.42 & -0.22 & 0.02 & 0.31 & -0.26 & 0.14 & -0.29 & 0.20 & 0.15 & -0.51 & 0.37 \\
\hline & Linear Reg. & -0.26 & 0.44 & -0.17 & 0.07 & 0.24 & -0.31 & 0.11 & -0.35 & 0.24 & 0.16 & -0.55 & 0.39 \\
\hline \multirow{3}{*}{ 苞 } & Mann Kendall & 0.21 & -0.28 & 0.07 & -1.47 & 1.75 & -1.54 & 0.42 & 0.07 & -0.14 & 0.63 & -1.47 & 1.47 \\
\hline & Şen's Method & 0.01 & -0.01 & 0.00 & -0.03 & 0.07 & -0.02 & 0.00 & 0.00 & 0.00 & 0.01 & -0.07 & 0.04 \\
\hline & Linear Reg. & 0.00 & -0.01 & 0.01 & -0.04 & 0.06 & -0.02 & 0.01 & 0.00 & -0.01 & 0.02 & -0.07 & 0.06 \\
\hline \multirow{3}{*}{ 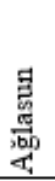 } & Mann Kendall & -2.38 & 1.29 & 1.19 & 0.10 & -1.29 & 0.79 & 0.79 & 0.59 & -2.18 & -0.79 & 0.30 & 0.00 \\
\hline & Şen's Method & -0.11 & 0.07 & 0.05 & 0.00 & -0.06 & 0.03 & 0.02 & 0.02 & -0.12 & -0.02 & 0.01 & 0.00 \\
\hline & Linear Reg. & 0.10 & 0.00 & 0.10 & 0.00 & -0.12 & 0.12 & 0.03 & 0.09 & -0.13 & -0.09 & 0.12 & -0.03 \\
\hline \multirow{3}{*}{ 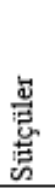 } & Mann Kendall & -2.92 & 2.02 & 0.21 & -0.95 & 1.28 & -1.03 & 0.66 & 0.66 & -1.69 & -0.78 & 1.03 & 0.00 \\
\hline & Şen's Method & -0.10 & 0.07 & 0.00 & -0.03 & 0.06 & -0.01 & 0.04 & 0.03 & -0.06 & -0.03 & 0.05 & 0.00 \\
\hline & Linear Reg. & -0.11 & 0.08 & 0.03 & -0.03 & 0.03 & 0.00 & 0.05 & 0.00 & 0.05 & -0.03 & 0.04 & -0.01 \\
\hline \multirow{3}{*}{ 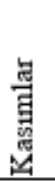 } & Mann Kendall & & & & & & & & & & & & \\
\hline & Şen's Method & 0.06 & 0.11 & -0.36 & 0.30 & -0.27 & 0.02 & -0.13 & 0.05 & 0.01 & 0.00 & -0.14 & 0.14 \\
\hline & Linear Reg. & 0.05 & 0.10 & -0.14 & 0.21 & -0.23 & 0.02 & -0.14 & 0.07 & 0.07 & 0.04 & -0.15 & 0.11 \\
\hline \multirow{3}{*}{$\begin{array}{l}\text { 总 } \\
\text { ต }\end{array}$} & Mann Kendall & -0.98 & -1.05 & 2.24 & -1.26 & 0.42 & 0.14 & 0.00 & 1.05 & -1.33 & -0.56 & -0.28 & 0.14 \\
\hline & Şen's Method & -0.03 & -0.06 & 0.08 & -0.04 & 0.01 & 0.00 & 0.00 & 0.01 & -0.01 & -0.01 & -0.02 & 0.00 \\
\hline & Linear Reg. & -0.04 & -0.05 & 0.08 & -0.04 & 0.02 & 0.02 & 0.00 & 0.03 & -0.03 & 0.01 & 0.00 & -0.01 \\
\hline \multirow{3}{*}{ 莺 } & Mann Kendall & & & & & & & & & & & & \\
\hline & Şen's Method & 0.15 & -0.42 & 0.27 & -0.86 & 0.98 & -0.12 & -0.36 & 0.27 & 0.09 & 0.67 & 0.29 & -0.96 \\
\hline & Linear Reg. & 0.15 & -0.42 & 0.27 & -0.86 & 0.98 & -0.12 & -0.36 & 0.27 & 0.09 & 0.67 & 0.29 & -0.96 \\
\hline
\end{tabular}


Table 8. The results of trend analysis tests for the 6 monthly standardized precipitation values.

\begin{tabular}{|c|c|c|c|c|c|c|c|c|c|c|c|c|c|}
\hline 营 & 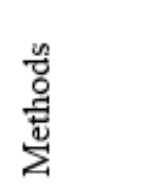 & 忌 & 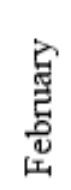 & 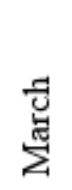 & 总 & 忍 & $\stackrel{\mathscr{\Xi}}{\Xi}$ & 当 & 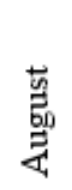 & 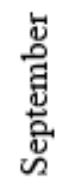 & $\begin{array}{l}\text { ע̀ } \\
\stackrel{0}{0} \\
\stackrel{0}{0}\end{array}$ & $\begin{array}{l}\breve{d} \\
\text { 葛 } \\
\text { 员 } \\
\text { 乙 }\end{array}$ & 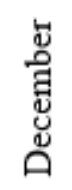 \\
\hline \multirow{3}{*}{ 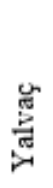 } & Mann Kendall & 0.20 & 0.36 & 1.08 & 0.41 & -0.59 & -1.29 & -0.03 & -1.04 & -0.41 & 0.01 & 0.78 & -0.20 \\
\hline & Şen's Method & 0.00 & 0.01 & 0.01 & 0.01 & -0.01 & -0.01 & 0.00 & -0.01 & 0.00 & 0.00 & 0.01 & 0.00 \\
\hline & Linear Reg. & 0.00 & 0.01 & 0.01 & 0.00 & -0.01 & -0.01 & 0.00 & -0.01 & 0.00 & 0.00 & 0.01 & 0.00 \\
\hline \multirow{3}{*}{ 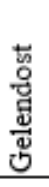 } & Mann Kendall & & & & & & & & & & & & \\
\hline & Şen's Method & -0.06 & 0.03 & 0.15 & -0.32 & -0.23 & 0.33 & 0.02 & -0.08 & -0.07 & 0.15 & -0.20 & 0.02 \\
\hline & Linear Reg. & 0.08 & 0.00 & 0.12 & -0.40 & -0.14 & 0.35 & 0.00 & -0.08 & 0.00 & 0.14 & -0.23 & 0.16 \\
\hline \multirow{3}{*}{ 营 } & Mann Kendall & & & & & & & & & & & & \\
\hline & Şen's Method & -0.31 & -0.05 & -0.24 & 0.45 & 0.50 & 0.01 & 0.03 & -0.09 & 0.10 & 0.23 & -0.64 & 0.48 \\
\hline & Linear Reg & -0.53 & -0.05 & -0.37 & 0.47 & 0.49 & -0.02 & -0.03 & -0.09 & 0.11 & 0.21 & -0.71 & 0.51 \\
\hline \multirow{3}{*}{ 泀 } & Mann Kendall & -0.42 & -0.98 & 1.26 & -0.42 & 1.26 & -1.47 & 0.07 & 0.56 & -0.07 & 0.00 & -1.54 & 0.91 \\
\hline & Şen's Method & -0.02 & -0.03 & 0.04 & -0.02 & 0.04 & -0.02 & 0.00 & 0.00 & 0.00 & 0.00 & -0.06 & 0.04 \\
\hline & Linear Reg & -0.03 & -0.03 & 0.04 & -0.02 & 0.04 & -0.01 & 0.00 & 0.01 & 0.01 & 0.00 & -0.07 & 0.04 \\
\hline \multirow{3}{*}{ 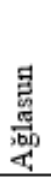 } & Mann Kendall & -1.98 & 1.29 & 1.39 & 0.59 & -0.40 & 1.09 & 0.89 & 0.99 & -0.69 & -1.39 & 0.10 & -0.10 \\
\hline & Şen's Method & -0.14 & 0.03 & 0.04 & 0.04 & -0.02 & 0.03 & 0.03 & 0.03 & -0.01 & -0.07 & 0.01 & 0.00 \\
\hline & Linear Reg. & -0.14 & 0.02 & 0.05 & 0.07 & -0.02 & 0.02 & 0.03 & 0.03 & -0.01 & -0.06 & 0.02 & -0.01 \\
\hline \multirow{3}{*}{ 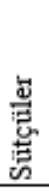 } & Mann Kendall & -2.73 & 1.67 & 0.83 & -0.61 & 2.05 & -0.23 & 1.74 & 0.83 & 0.38 & -1.36 & 0.68 & -0.45 \\
\hline & Şen's Method & -0.13 & 0.05 & 0.05 & -0.02 & 0.08 & -0.01 & 0.02 & 0.01 & 0.00 & -0.04 & 0.03 & -0.01 \\
\hline & Linear Reg. & -0.13 & 0.05 & 0.05 & -0.03 & 0.07 & -0.01 & 0.02 & 0.01 & 0.01 & -0.04 & 0.02 & -0.01 \\
\hline \multirow{3}{*}{ 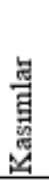 } & Mann Kendall & & & & & & & & & & & & \\
\hline & Şen's Method & -0.06 & 0.04 & -0.55 & 0.16 & -0.17 & -0.06 & 0.04 & 0.07 & 0.01 & 0.03 & -0.08 & 0.20 \\
\hline & Linear Reg. & -0.05 & 0.04 & -0.16 & 0.17 & -0.08 & 0.07 & 0.00 & 0.07 & 0.04 & -0.03 & -0.19 & 0.12 \\
\hline \multirow{3}{*}{ 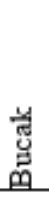 } & Mann Kendall & -1.07 & -1.75 & 1.13 & -0.56 & 1.75 & 0.73 & 0.68 & 1.24 & -1.24 & 0.45 & -0.39 & 0.34 \\
\hline & Şen's Method & -0.04 & -0.05 & 0.04 & -0.01 & 0.04 & 0.01 & 0.01 & 0.01 & -0.02 & 0.01 & -0.02 & 0.01 \\
\hline & Linear Reg. & -0.04 & -0.04 & 0.04 & -0.02 & 0.04 & 0.02 & 0.01 & 0.01 & -0.02 & 0.01 & -0.01 & 0.01 \\
\hline \multirow{3}{*}{ 褐 } & Mann Kendall & & & & & & & & & & & & \\
\hline & Şen's Method & 0.58 & 0.09 & 0.94 & -1.07 & 0.05 & -0.59 & -0.34 & -0.15 & -0.02 & 0.85 & 0.11 & -0.45 \\
\hline & Linear Reg & 0.58 & 0.09 & 0.94 & -1.07 & 0.05 & -0.59 & -0.34 & -0.15 & -0.02 & 0.85 & 0.11 & -0.45 \\
\hline
\end{tabular}


Table 9. The results of trend analysis tests for the 9 monthly standardized precipitation values.

\begin{tabular}{|c|c|c|c|c|c|c|c|c|c|c|c|c|c|}
\hline 岂 & $\begin{array}{l}\frac{n}{0} \\
\frac{3}{2} \\
\sum_{2}^{ \pm}\end{array}$ & 忌 & 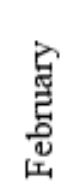 & 总 & 寻 & 憂 & $\stackrel{\Xi}{\Xi}$ & 坣 & 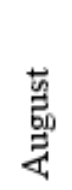 & 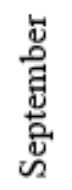 & 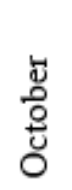 & 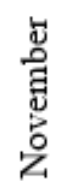 & 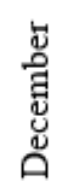 \\
\hline \multirow{3}{*}{ 莺 } & Mann Kendall & -0.13 & 0.87 & 0.62 & 0.03 & -0.31 & -1.46 & -0.10 & -2.04 & -0.66 & 0.73 & 1.43 & 0.06 \\
\hline & Şen's Method & 0.00 & 0.01 & 0.01 & 0.00 & 0.00 & -0.01 & 0.00 & -0.01 & 0.00 & 0.01 & 0.02 & 0.00 \\
\hline & Linear Reg. & 0.00 & 0.03 & 0.01 & 0.00 & -0.01 & -0.01 & 0.00 & -0.01 & -0.01 & 0.01 & 0.02 & 0.00 \\
\hline \multirow{3}{*}{ 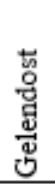 } & Mann Kendall & & & & & & & & & & & & \\
\hline & Şen's Method & -0.01 & 0.10 & -0.01 & -0.41 & -0.05 & 0.25 & 0.02 & -0.03 & -0.07 & 0.11 & -0.09 & 0.18 \\
\hline & Linear Reg. & -0.02 & 0.00 & 0.01 & -0.39 & -0.05 & 0.24 & 0.03 & -0.01 & 0.04 & 0.12 & -0.12 & 0.26 \\
\hline \multirow{3}{*}{$\begin{array}{l}\text { 劳 } \\
\text { m }\end{array}$} & Mamn Kendall & & & & & & & & & & & & \\
\hline & Şen's Method & -0.05 & -0.13 & -0.39 & 0.33 & 0.41 & 0.03 & 0.04 & 0.00 & 0.21 & 0.27 & -0.50 & 0.64 \\
\hline & Linear Reg. & -0.51 & -0.13 & -0.42 & 0.40 & 0.40 & -0.07 & 0.13 & -0.02 & 0.19 & 0.24 & -0.65 & 0.61 \\
\hline \multirow{3}{*}{ 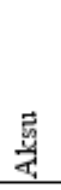 } & Mann Kendall & 0.07 & -0.91 & 1.12 & -0.91 & 0.98 & -0.77 & 0.00 & 1.33 & 0.21 & -0.35 & -1.12 & 1.33 \\
\hline & Şen's Method & 0.01 & -0.03 & 0.03 & -0.02 & 0.01 & -0.01 & 0.00 & 0.02 & 0.00 & -0.01 & -0.07 & 0.05 \\
\hline & Linear Reg. & -0.03 & -0.02 & 0.05 & -0.02 & 0.03 & -0.02 & -0.01 & 0.03 & 0.01 & 0.00 & -0.07 & 0.06 \\
\hline \multirow{3}{*}{ 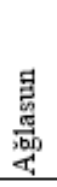 } & Mamn Kendall & -1.48 & 1.29 & 1.39 & 1.88 & 0.10 & 0.59 & 1.09 & 0.99 & -0.40 & -1.29 & -0.10 & -1.09 \\
\hline & Şen's Method & -0.12 & 0.06 & 0.05 & 0.10 & 0.01 & 0.03 & 0.03 & 0.02 & -0.01 & -0.11 & -0.02 & -0.07 \\
\hline & Linear Reg. & -0.11 & 0.05 & 0.06 & 0.09 & 0.00 & 0.04 & 0.02 & 0.02 & -0.02 & -0.08 & -0.01 & -0.04 \\
\hline \multirow{3}{*}{$\begin{array}{l}\vec{y} \\
\text { 总 } \\
\text { 蒡 } \\
\end{array}$} & Mann Kendall & -2.80 & 0.45 & 0.38 & -0.83 & 1.06 & -0.15 & 1.59 & 0.98 & 0.23 & -0.53 & 0.76 & 0.68 \\
\hline & Şen's Method & -0.14 & 0.02 & 0.02 & -0.02 & 0.03 & -0.01 & 0.02 & 0.01 & 0.01 & -0.02 & 0.06 & 0.03 \\
\hline & Linear Reg. & -0.14 & 0.02 & 0.02 & -0.04 & 0.03 & 0.00 & 0.02 & 0.01 & 0.02 & -0.02 & 0.05 & 0.03 \\
\hline \multirow{3}{*}{ 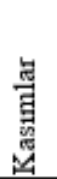 } & Mann Kendall & & & & & & & & & & & & \\
\hline & Şen's Method & -0.01 & -0.11 & -0.54 & 0.03 & -0.24 & -0.05 & 0.06 & 0.15 & 0.17 & 0.10 & 0.10 & 0.27 \\
\hline & Linear Reg. & -0.10 & -0.07 & -0.35 & 0.05 & -0.12 & -0.03 & 0.06 & 0.14 & 0.10 & 0.05 & -0.04 & 0.31 \\
\hline \multirow{3}{*}{ 茨 } & Mann Kendall & -0.90 & -1.35 & 1.35 & -0.68 & 0.96 & 0.51 & 0.90 & 1.80 & -0.56 & 0.51 & -0.23 & 0.96 \\
\hline & Şen's Method & -0.04 & -0.04 & 0.05 & -0.02 & 0.03 & 0.01 & 0.01 & 0.01 & -0.01 & 0.01 & -0.01 & 0.03 \\
\hline & Linear Reg. & -0.04 & -0.03 & 0.05 & -0.03 & 0.03 & 0.01 & 0.01 & 0.01 & -0.02 & 0.02 & -0.01 & 0.03 \\
\hline \multirow{3}{*}{ 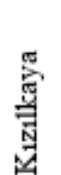 } & Mann Kendall & & & & & & & & & & & & \\
\hline & Şen's Method & -0.01 & -0.44 & 0.20 & -1.19 & -0.09 & -0.79 & -0.07 & 0.13 & 0.16 & 1.21 & 0.82 & 0.36 \\
\hline & Linear Reg. & -0.01 & -0.44 & 0.20 & -1.19 & -0.09 & -0.79 & -0.07 & 0.13 & 0.16 & 1.21 & 0.82 & 0.36 \\
\hline
\end{tabular}


Table 10. The results of trend analysis tests for the 12 monthly standardized precipitation values.

\begin{tabular}{|c|c|c|c|c|c|c|c|c|c|c|c|c|c|}
\hline 莺 & 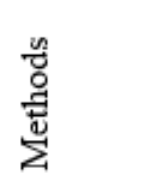 & 氖 & 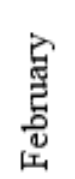 & $\begin{array}{l}\text { 总 } \\
\text { 帘 }\end{array}$ & 寻 & 憂 & 岑 & 坣 & 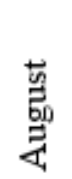 & 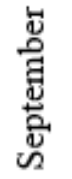 & $\begin{array}{l}\text { 岁 } \\
\stackrel{0}{0} \\
\stackrel{+}{0} \\
0\end{array}$ & $\begin{array}{l}\text { 岁 } \\
\text { 获 } \\
\text { 总 } \\
\text { 艺 }\end{array}$ & 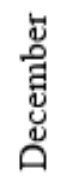 \\
\hline \multirow{3}{*}{ 龸 } & Mann Kendall & -0.15 & 0.29 & 0.78 & 0.29 & -0.99 & -1.04 & 0.50 & -0.69 & 0.20 & 0.10 & 0.92 & 0.15 \\
\hline & Şen's Method & 0.00 & 0.00 & 0.01 & 0.00 & -0.01 & -0.01 & 0.00 & 0.00 & 0.00 & 0.00 & 0.01 & 0.00 \\
\hline & Linear Reg. & 0.00 & 0.01 & 0.01 & 0.00 & -0.01 & 0.00 & 0.01 & -0.01 & 0.00 & 0.00 & 0.01 & 0.00 \\
\hline \multirow{3}{*}{ 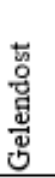 } & Mann Kendall & & & & & & & & & & & & \\
\hline & Şen's Method & 0.03 & 0.18 & 0.01 & -0.21 & -0.10 & 0.17 & 0.02 & -0.08 & -0.11 & 0.13 & -0.18 & 0.17 \\
\hline & Linear Reg. & 0.06 & 0.00 & -0.02 & -0.37 & -0.06 & 0.23 & 0.00 & -0.08 & -0.34 & 0.15 & -0.10 & 0.21 \\
\hline \multirow{3}{*}{ 㗊 } & Mamn Kendall & & & & & & & & & & & & \\
\hline & Şen's Method & -0.12 & -0.14 & -0.46 & 0.18 & 0.28 & -0.05 & 0.11 & -0.09 & 0.20 & 0.34 & -0.48 & 0.75 \\
\hline & Linear Reg. & -0.55 & -0.17 & -0.42 & 0.21 & 0.29 & -0.17 & 0.11 & -0.04 & 0.18 & 0.03 & -0.56 & 0.81 \\
\hline \multirow{3}{*}{$\begin{array}{l}\vec{n} \\
\text { 党 }\end{array}$} & Mann Kendall & -0.35 & -0.84 & 1.33 & -0.14 & 1.33 & -0.98 & -0.07 & 0.70 & 0.14 & 0.00 & -1.26 & 0.98 \\
\hline & Şen's Method & -0.01 & -0.04 & 0.03 & -0.01 & 0.03 & -0.02 & 0.00 & 0.01 & 0.00 & 0.00 & -0.05 & 0.04 \\
\hline & Linear Reg. & -0.03 & -0.02 & 0.04 & -0.02 & 0.04 & -0.01 & 0.00 & 0.01 & 0.02 & 0.00 & 0.06 & 0.05 \\
\hline \multirow{3}{*}{ 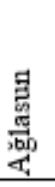 } & Mann Kendall & -1.88 & 0.89 & 1.19 & 0.89 & 0.30 & 1.19 & 1.88 & 0.79 & -0.59 & -1.29 & -0.40 & -0.99 \\
\hline & Şen's Method & -0.13 & 0.04 & 0.04 & 0.05 & 0.01 & 0.05 & 0.03 & 0.03 & -0.02 & -0.07 & -0.01 & -0.03 \\
\hline & Linear Reg. & -0.12 & 0.04 & 0.04 & 0.06 & -0.02 & 0.03 & 0.03 & 0.02 & -0.02 & -0.07 & 0.01 & -0.01 \\
\hline \multirow{3}{*}{ 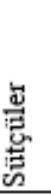 } & Mann Kendall & -3.03 & 0.23 & 0.00 & -0.98 & 0.83 & 0.30 & 2.27 & 1.36 & 0.45 & -0.91 & 0.76 & 1.06 \\
\hline & Şen's Method & -0.16 & 0.01 & 0.00 & -0.03 & 0.02 & 0.01 & 0.03 & 0.02 & 0.01 & -0.03 & 0.04 & 0.05 \\
\hline & Linear Reg. & -0.14 & 0.02 & 0.02 & -0.05 & 0.02 & 0.00 & 0.02 & 0.01 & 0.02 & -0.02 & 0.05 & 0.04 \\
\hline \multirow{3}{*}{ 㒮 } & Mann Kendall & & & & & & & & & & & & \\
\hline & Şen's Method & -0.13 & -0.09 & -0.51 & 0.02 & -0.25 & -0.01 & 0.09 & 0.17 & 0.20 & 0.06 & -0.14 & 0.31 \\
\hline & Linear Reg. & -0.16 & -0.13 & -0.10 & 0.00 & -0.16 & 0.00 & 0.19 & 0.16 & 0.13 & 0.05 & -0.15 & 0.26 \\
\hline \multirow{3}{*}{ 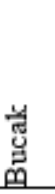 } & Mann Kendall & -1.18 & -1.80 & 1.02 & -0.79 & 0.90 & 0.45 & 0.56 & 0.79 & -0.34 & 0.39 & 0.00 & 0.45 \\
\hline & Şen's Method & -0.04 & -0.05 & 0.03 & -0.02 & 0.03 & 0.01 & 0.01 & 0.01 & -0.01 & 0.01 & 0.00 & 0.02 \\
\hline & Linear Reg. & -0.04 & -0.05 & 0.04 & -0.02 & 0.03 & 0.01 & 0.01 & 0.01 & -0.02 & 0.01 & 0.00 & 0.03 \\
\hline \multirow{3}{*}{$\begin{array}{l}\text { 究 } \\
\text { 尝 } \\
\text { 音 }\end{array}$} & Mann Kendall & & & & & & & & & & & & \\
\hline & Şen's Method & 0.19 & -0.17 & 0.72 & -1.29 & -0.20 & -0.86 & -0.10 & 0.09 & 0.16 & 1.09 & 0.45 & -0.08 \\
\hline & Linear Reg & 0.19 & -0.17 & 0.72 & -1.29 & -0.20 & -0.86 & -0.10 & 0.09 & 0.16 & 1.09 & 0.45 & -0.08 \\
\hline
\end{tabular}

As in Table 2, the Mann Kendall values were not given for some stations (Gelendost, Barla, Kasımlar, Kizılkaya). It was not observed any meaningful value for these stations because of the fact that the 3,6,9 and 12 months standardized values of the historical precipitation records were too short to apply this method (Table 7, 8, 9 and $10)$.

According to Table 7,8,9 and 10 for all standardized precipitation values of Yalvaç station, the negative trend was seen in May, June, July and August monthsin applying Mann Kendall 
test. In May, it is seen a decrease in precipitation values according to the three tests. In April and November, the negative values of Sen's test and Linear Regression slopes of Gelendost station show a decrease in precipitation. For Barlastation, in January, it is seen negative trend while in September, October and December it is seen positive trend. In Aksu station, the negative trends are seen for February, April, and November months. For Ağlasun Station, it is seen negative trends in May, April and October months while for Sütçüler station it is seen negative trends in January and October. For Kasimlar station, it is observed a decrease in precipitation in May. For Bucak station, the test values of January and February show that these months have critical mean because the values are negative. In Kizilkaya station, the decrease on precipitation is seen for June, especially.

The according to the results of the tests, a decreasing trend has been observed in most of the nine stations. So, the existence of a trend is indicative of climatically changes in the region for long term.

\section{CONCLUSION}

In this study, it was examined the monthly precipitation trends and the monthly standardized precipitation trends for nine stations having different time intervals in Lakes Region, Turkey. In the analysis of trends for historical precipitation records according to Mann Kendall andSen's tests and Linear Regression, the almost all stations showed the negative trends. Especially, in January and February months, the negative trends were observed in most of region. In the second part of study, 3,6,9 and12 monthly Standardized Precipitation Index (SPI) values of nine stations were examined by Mann Kendall and Sen's tests and Lineer Regression. The negative trends were seen in April and May (the spring months) for the most of stations (Yalvaç, Aksu, Ağlasun, Gelendost and Kasımlar stations) situated at the west of region. However, for Barla, Ağlasun andSütçüler stations, the decreasing trends were seen in October (autumn). It was seen that the trend analysis of historical records were similar to the trend analysis of the standardized precipitation values of region. The decreasing of monthly precipitations and standardized precipitation values shows the increasing of drought risk. Hence, by realized the meteorological drought monitoring plans for region, the hydrological and agricultural drought can be prevented.

\section{REFERENCES}

[1]. Türkes M.Climate Change: The Relations Framework Convention for Climate Change of Turkey and Climate Change Policy. The TUBITAK Vision 2023: The Technology Foresight Project, Science and Technology Strategies, The Environment and Sustainable Development Panel and the Report of Vision and Foresight, 2002; October, Ankara (in Turkish).

[2]. Türkeş M. The Relations Framework Convention for Climate Change of Turkey. The access address: http://www.meteor.gov.tr/2003/arge/iklimd egis/iklimdegis10.htm. 2003 (in Turkish) (accessed 14 Jun 2017)

[3]. Ediger V.Ş. The Size of International Relations of Global Climate Change and Policies of Turkey. Mülkiye, 32-259 (2008) 133-158 (in Turkish).

[4]. Kalaycı S. Kahya E. Detection of Water Quality Trends in the Rivers of the Susurluk Basin. J. of Engineering and Environmental Science, 22 (1998) 503-514.

[5]. Şen Z. The Climate Change and Its Effect On Water Resources. The World Water Day, March 22, The Panel of The Climate Change Impacts on Water and Energy Resources, 2005. (in Turkish).

[6]. Helsel D.R., Hirsch R.M. Statistical Methods in Water Resources.Techniques of Water-Resources Investigations of the United States Geological Survey Book 4, Hydrologic Analysis and Interpretation Elsevier, 1992.

[7]. Keskin M.E., Taylan E.D. and Aslanbaş T. An Investigation of Water Potential of Lake Eğirdir. Procedia Earth and Planetary Science, 15 (2015) 244-248. 
[8]. Serrano A., Mateos V.L., Garcia J.A. Trend Analysis of Monthly Precipitation Over the Iberian Peninsula fort the period 19211995.Phys. Chem. Earth (B), 24-1,2 (1999) U-90.

[9]. Türkeş M. Spatial and Temporal Analysis of Annual Rainfall Variations in Turkey. International Journal of Climatology, 16 (1996) 1057-1076.

[10]. Gan Y.T. Hydroclimatic Trends and Possible Climatic Warming in the Canadian Praires. Water Resources, 34-11 (1998) 3009-3015.

[11]. Topaloğlu F., Tülücü K., Cetin M., Yücel A. The Statistical Preliminary Analysis of Some Hydrological Data and Applications. The Journal of The Agriculture Faculty of The Çukurova University, 12-4 (1997) 2130 (in Turkish).

[12]. Yue S., Wang C.Y. Regional Streamflow Trend Detection with Consideration of Both Temporal and Spatial Correlation. International Journal of Climatology, 22 (2002) 933-946.

[13]. Yue S., Hashino M. Long term trends of annual and monthly precipitation in Japan. Journal of the American Water Resources Association, 39-3 (2003) 587- 596.

[14]. Rahmat S.N., Jayasuriya N., Bhuiyan M. Trend Analysis of Drought Using Satndardised Precipitation Index (SPI) in Victoria, Australia. 34th Hydrology and Water Resources Symposium November, Sydney, Australia, (2012) 19-22

[15]. Jha S., Seghal V., Raghava R. Spatiotemporal Trends of Standardized Precipitation Index for Meteorological Drought Analysis across Agroclimatic
Zones of India. National Symposium on Advances in Weather and Climate Services TROPMET. 20 May Kolkata, India, 2010.

[16]. Campara P., Morales M. Trend analysis by a piecewise linear regression model applied to surface air temperatures in Southeastern Spain, Nonlin. Processes Geophys. Discuss, (2016).

[17]. Rehman S. Long-Term Wind Speed Analysis and Detection of its Trends Using Mann-Kendall Test and Linear Regression Method. Arab. J. Sci. Eng., 38 (2013) 421437.

[18]. Bacanlı Ü.G.Trend analysis of precipitationanddrought in the Aegeanregion, Turkey. Meteorol. Appl. 24 (2017) 239-249.

[19]. Keskin M.E., Terzi Ö., Taylan E.D. The Meteorological Drought Analysis of Isparta Region. 1.The Turkey Climate Changes Congress, (2007) 350-359 (in Turkish).

[20]. Gibbons R.D., Coleman D.E. Statistical Methods for Detection and Quantification of Environmental Contamination,2001.387.

[21]. DeLurgio Stephen A. Forecasting principles and Applications. Mc-Grow-Hill New York,1998.

[22]. Mckee T.B., Doesken N.J., Kleist J. The Relationship of Drought Frequency and Duration to time Scales. Eight Conference on Applied Climatology, 1993.17-22 January Anaheim, California.

[23]. Keskin M.E., Terzi Ö., Taylan D., Küçükyaman D. Meteorological drought analysis using data-driven models for the Lakes District, Turkey. Hydrol. Sci. J., 54-6 (2009) 1114-1124. 